\title{
The Influence of Societal Changes in the Late Second Temple Period on the Functions and Composition of Psalms
}

\section{Pajunen, Mika Sakari}

2019

Pajunen, M S 2019, ' The Influence of Societal Changes in the Late Second Temple Period on the Functions and Composition of Psalms ' , SJOT : Scandinavian journal of the Old Testament. , vol. 33 , no. 2 , pp. 164-184 . https://doi.org/10.1080/09018328.2019.1686281

http://hdl.handle.net/10138/309607

https://doi.org/10.1080/09018328.2019.1686281

submittedVersion

Downloaded from Helda, University of Helsinki institutional repository.

This is an electronic reprint of the original article.

This reprint may differ from the original in pagination and typographic detail.

Please cite the original version. 
This is an original manuscript / preprint of an article published by Taylor \& Francis in Scandinavian Journal of the Old Testament 33/2 (2019): 164-184, available online: http://www.tandfonline.com/doi/abs/10.1080/09018328.2019.1686281

There are 50 free copies of the published version available at https://www.tandfonline.com/eprint/VUVJMFSSKPFAAMGGYOXF/full?target=10.1080/090183 $\underline{28.2019 .1686281}$

The Influence of Societal Changes in the Late Second Temple Period on the Functions and Composition of Psalms

Mika S. Pajunen

University researcher, Docent in Old Testament Studies

Faculty of Theology

P.O. Box 4 (Vuorikatu 3)

00014 University of Helsinki

Finland

mika.s.pajunen@helsinki.fi

\section{ABSTRACT}

This study deals with the question of why there is a Book of Psalms in the Hebrew Bible. In previous studies the question has typically been seen as an either-or issue between liturgical, educational, and prophetic use of the psalms. It is shown in this study that all these different uses persisted at least until the end of the Second Temple period, were common to both now biblical and apocryphal psalms, and together contributed to the emergence of a canonical book of psalms. While it will be demonstrated that a division of psalm material cannot be based on such functional indicators or a sense of prestige given to a specific collection of psalms, it will be argued that the Maccabean revolt led to a historical process that incidentally created a watershed between most psalms composed before and after this gradual process. Such markers are visible in the style of the psalms and their functional 
markers but most of all in a marked shift of perspective from a more general aim to influence the whole people of Israel common to earlier psalms to the consistent use of group perspectives in later works. This shift in the perspective of psalms also contributed to the recontextualization of many earlier psalms to new settings, which further contributed to a later perceivable boundary between the earlier and later psalm material. By focusing on the historical processes instigated by radical societal changes this study offers fresh alternatives for understanding the complex developments that led to the eventual canonization of a book of psalms.

KEYWORDS: psalms, Second Temple Judaism, psalm collections, Qumran studies, functions of psalms, psalms and identity

\section{Introduction ${ }^{1}$}

The Book of Psalms is one of the most treasured books of the Hebrew Bible in both the Jewish and Christian traditions. Thus, it is perhaps a bit surprising that there is presently no consensus among scholars concerning the reasons why the Book of Psalms came to be included in the canon of the Hebrew Bible. The old consensus was that the Psalter was the hymn book of Second Temple Judaism from which psalms could be drawn for various liturgical purposes. Much of Psalm scholarship before the 1980s was consequently centered on discovering the possible Sitz im Leben of the individual Psalms in the cult of ancient Israel. A lasting change to this situation was only brought about by Gerald Wilson's groundbreaking study The Editing of the Hebrew Bible published over three decades ago in $1985 .{ }^{2}$ Wilson's studies shifted the focus of the entire field of Psalm studies from the individual Psalms to collections of Psalms and the editorial principles of their compilation.

After this shift, most of the scholarly focus was naturally first on the now canonical MT Psalter that was increasingly seen as a compilation also intended for instruction, not just liturgy, but soon another large arrangement of psalms from the Qumran Caves, 11QPs ${ }^{\mathrm{a}}$, was brought more fully into the discussion. This initiated a lively debate about the differences of these two collections, but it also shifted the discussion somewhat from the functions of specific collections to the authoritativeness of a given collection of psalms. ${ }^{3}$ This debate has come to a stalemate in the last decade on the question of whether the 11QPsa collection of psalms should be considered a "true" alternative Psalter

\footnotetext{
${ }^{1}$ This paper was first presented in Copenhagen in 2014 at the meeting: Material Philology in the Dead Sea Scrolls: New Approaches for New Text Editions. I wish to extend my warmest gratitude to the organizers of this meeting and to its generous sponsors.

${ }^{2}$ Wilson: 1985.

${ }^{3}$ For the emphasis on collections and editing in the last thirty years of Psalms research, see, e.g., deClaissé-Walford: 2014a, 1-11. Gericke: 2014, 43-45.
} 
comparable in status to the proto-MT Psalter or a strictly secondary arrangement. Thus, the questions of functions and authoritativeness still persist in today's psalm studies and are intertwined, as this study will also show. In the following I will first highlight some central aspects of recent efforts to deal with these questions by myself and others. These studies will serve to demonstrate even more clearly how complicated the questions concerning the emergence of a fixed authoritative Book of Psalms really are. After that, aspects that may be a part of the solution will be presented.

\section{The Illusion of an Authoritative Collection of Psalms}

Much of my past research has centered on the so-called Qumran Psalms manuscripts containing some of the now canonical Psalms, and particularly on the various collections of what are typically labeled as "apocryphal" or "non-canonical psalms." Like several other scholars recently (e.g., Eva Mroczek), ${ }^{5}$ I have arrived at the conclusion that there in all likelihood was no fixed authoritative collection of psalms before the end of the Second Temple period. Rather there is currently evidence of at least three large arrangements of Psalms that all continued to be at least slightly edited throughout this period. The proto-Masoretic Psalter was chronologically the first of these, and the Septuagint Psalter and the 11QPs ${ }^{\text {a }}$ Psalter are both based on it and provide evidence for the further editing and especially Davidizing of the large collections of psalms. ${ }^{6}$ Yet they and the current MT Psalter demonstrate that the proto-MT Psalter could still be altered and indeed that other forms of the Psalter could be regarded as, if not more, authoritative than the proto-MT Psalter by certain groups.

Furthermore, there is nothing that would distinguish the now canonical Psalms as a group of compositions during the late Second Temple period from most of the psalms left out of the canon. All these psalms were used as authoritative writings by one or more groups of Judaism during this period and many of the now apocryphal psalms were probably as influential as the canonical ones - at least they were quoted and alluded to in the same way ${ }^{7}$ - and some of them, such as Psalms 151155 and the Psalms of Solomon, were translated into other languages. In fact, it may be questioned how fixed the Psalter was even after the end of the Second Temple period; for instance, Psalms 151155 are evidence that some of these "apocryphal" psalms maintained their influence at later times,

\footnotetext{
${ }^{4}$ For the background of this paper, see especially, Pajunen: 2013, 2014, 139-63, and "Bible" in T \& T Clark Companion to the Dead Sea Scrolls, forthcoming 2018.

${ }^{5}$ E.g., Mroczek: 2011, 241-269, and 2015, 2-35.

${ }^{6}$ See further Pajunen: 2014, 149-157. There is no manuscript evidence for the proto-MT Psalter. It is basically the "final form" of the MT Book of Psalms that preceded later, mostly, minor changes demonstrated by the LXX Psalter and the more extensive Qumran psalms manuscripts.

${ }^{7}$ For details about the quotations and allusions, see Pajunen: 2014, 158.
} 
and others probably did as well, although the evidence has not been preserved. One such example is the exorcism of Satan in 11QApocryphalPsalms (11Q11 V 4-VI 3), which has possibly been used in some form all the way to medieval times. ${ }^{8}$

Finally, it also has to be realized that even though the 41 so-called Qumran Psalms manuscripts containing parts of at least one Psalm now in the MT Psalter are often taken as some sort of unified evidence for the influence of a specific Book of Psalms during the late Second Temple period, it is a distinct possibility that none of these manuscripts actually contained as many Psalms as are now found in the MT Psalter, viz., 150. ${ }^{9}$ This illusion may have been partly created by typical editorial principles guided by an ideal conception of a literary work that have influenced scholarly thinking both explicitly and implicitly. ${ }^{10}$ But when the so-called Psalms manuscripts are inspected individually it quickly becomes obvious that they cannot be used as unified evidence for any large arrangement of psalms. ${ }^{11}$ There are several scrolls among these manuscripts that may originally have been very long, like 4QPs ${ }^{\mathrm{a}}$, and thus theoretically could have contained the now full 150 Psalm Psalter. But most attempts, thus far, at reconstructing the lengths of these fragmentary scrolls have been somehow dependent on the idea that the order of psalms was similar to the MT or the number of psalms should have been the same as in the MT, and according to the surviving evidence this was not the case. ${ }^{12}$ Rather most of the Psalms manuscripts were probably quite limited collections containing a small number of Psalms or even just one Psalm, ${ }^{13}$ as is frequently the case with Psalm 119 (4QPs $\left.^{\mathrm{g}}, 4 \mathrm{QPs}{ }^{\mathrm{h}}, 5 \mathrm{Q} 5\right)$, which was copied alone, perhaps for meditational purposes. ${ }^{14}$

These Psalms manuscripts are not copies of a specific book of psalms and cannot be used as direct evidence for the existence of such an authoritative book. Furthermore, if there is any evidence for a book of psalms in some of these manuscripts, it is not the MT book of psalms, as many Hebrew Bible scholars seem to presume, because almost half of the manuscripts containing more than one Psalm directly contradict the MT arrangement, and there are only two possible cases where the MT arrangement is supported against another arrangement. There might be some amount of support for another relatively large arrangement ending in a sequence of psalms like that found in $11 \mathrm{QPs}^{\mathrm{a}}$ (possibly at least $4 \mathrm{QPs}^{\mathrm{e}}$ and $11 \mathrm{QPs}^{\mathrm{b}}$ ). But even if this were the case, only a few of the Psalm

\footnotetext{
${ }^{8}$ See, Bohak: 2008, 303-305. For an analysis of the psalm, see Pajunen: 2015a, 145-149.

${ }^{9}$ The number of the so-called Psalms manuscripts is taken from the most recent listing by Flint: 2014, 209.

${ }^{10}$ For such editorial conceptions, see, for instance, Driscoll: 2010, 87-95. Nicholls: 2014, 15.

11 This kind of return to the primary manuscript evidence and the importance of understanding each manuscript on its own has been emphasized by scholars advocating perspectives of the new philology. See, for example, Driscoll: 2010 , 87-104. Nicholls: 2014, 12. For the background and beginnings of new philology, see Spiegel: 2014, 39-50.

${ }^{12}$ Cf. Jain: 2014.

${ }^{13}$ Cf. Lange: 2012, 297-309.

${ }^{14}$ Cf. Flint: 1997.
} 
manuscripts would represent significant exemplars of this type of large collection of psalms, and it is possible that none of them had the entire $11 \mathrm{QPs}^{\mathrm{a}}$-type collection scholars seem to envision. ${ }^{15}$

Thus, psalms cannot be divided into "canonical" and "non-canonical" groups in the late Second Temple period. If the mention of "David" in some compositions, like 4QMMT, is meant to refer to psalms as a group (see, e.g., 4Q397 14-21 9-11), which is questionable, it is another overall category label similar to "the Law" and "the Prophets" that does not define its exact content. ${ }^{16}$ If this assessment of the overall status of psalmody is correct, the basic question that remains to be answered is the one many other scholars have also arrived at when discussing the status of different compositions during this general time period, that is, there is this great plurality in texts and text types that seems to have been the accepted norm during the late Second Temple period, ${ }^{17}$ but in the end there still is a particular collection of texts and the specific text types now found in the Hebrew Bible, so what happened and when? ${ }^{18}$

\section{Changes in Discourse and Psalmody}

The question is much too broad to answer in a single study but the results of my previous research have led me to consider some aspects of the psalm material that might be approached by the question: Is there anything in the historical process that could illuminate some aspects of the canonical process in the case of psalmody ${ }^{19}$ It seems clear from the aspects just presented that investigating authority is not particularly helpful in this respect, and it is equally obvious that studying the specific arrangements found in psalm collections is equally fruitless on its own. Such aspects need to be supplemented by considering the perceivable changes in psalmody from a historical perspective. Because while there seem to be no major differences in how specific psalms are regarded before the turn of the era, there still appears to be a marked change in the psalms themselves that may have helped in a later drawing of boundaries. In this article I will investigate what these changes are, but I will begin the analysis by revealing what is taken to be the constitutive phase when these changes in psalmody took place.

\footnotetext{
${ }^{15}$ For a fuller treatment of this manuscript evidence, see Pajunen: 2014, 140-149.

${ }^{16}$ Cf. Lim: 2013.

${ }^{17}$ In fact such diversity seems to have been the norm rather than the exception in pre-printing age manuscript cultures; see, e.g., Driscoll: 2010, 90. Nicholls: 2014, 12.

${ }^{18}$ E.g., Brooke: 2011, 13-36.

${ }^{19}$ For the terms "canonical process" and "historical process" in this context, see, e.g., Ulrich: 2011, 47-64. Brooke: 2011, $16-18$.
} 
This change seems to happen roughly around the latter half of the second century BCE and to be related to the changes happening on the societal level. This is the period after the Maccabean revolt when the Judean literate elite was divided into specific groups, such as the Pharisees and Essenes, with differing, often contradictory, aims. The gradual change in the discourse setting of the psalms brought about by this fragmentation of the elite is possibly the factor that most prominently creates a sense of difference between psalms composed before and after this period and also incidentally leads to the situation where the earlier works need to be explicitly reinterpreted in order for them to be directly meaningful for the settings of specific groups. Thus, the discourse setting gradually changes during the latter half of the second century BCE: all new psalms are written directly for this setting whereas the earlier ones need to be reinterpreted, which eventually may have created a seeming barrier between these groups of psalms. But it has to be emphasized that this is not yet a division into canonical and non-canonical material nor is it a division into sectarian and non-sectarian psalms, but into compositions stemming from different discourse settings, i.e., the earlier setting where the whole people are perceived as the potential audience influenced by and using the psalms and the later where the authors limited their efforts to their own specific groups.

Because it is perceived that there was some kind of gradual change in psalmody in the latter half of the second century BCE, issues will be discussed in the following in relation to psalmody written before, during, and after this rough dividing period. Dating of psalms is of course notoriously difficult, but even if the case of individual psalms might be debated, the broad division can be maintained. Therefore, from now on the designation earlier psalms will be used for those psalms probably written before this time period, consisting of most of the Psalms now in the Psalter as well as many of the so-called apocryphal psalms found in the Qumran Psalm scrolls (4QPs ${ }^{\mathrm{f}}, 11 \mathrm{QPs}{ }^{\mathrm{a}+\mathrm{b}}$, but also, for instance, the psalm in 4Q380 1) and new psalms for the likely later psalms, like those probably written by the Qumran movement (e.g., Hodayot and the Songs of the Sage) and the Psalms of Solomon. In addition, I will point out several psalms that have been quite plausibly dated by scholars to the interim period, and consequently feature some characteristics from both discourse settings, such as the psalms in 4QNon-Canonical Psalms B and Psalm 154.

In the following it will first be discussed whether there was a difference in the way the earlier and new psalms were used because the functions of psalms have been frequently brought up as milestones in the canonization process of the psalms, that is, mainly the idea that the now canonical psalms had special status because they were seen as records of history, ethical instruction, and most importantly as prophecies. In fact, I too believe the main reason that there is a Psalter in the Hebrew Bible is that it had been studied for hundreds of years, not just used in liturgies. But whether these 
different functions can be used to make divisions between psalms from these different time periods is something that has to be investigated here. After this it will be briefly considered whether material aspects related to the psalm collections as well as some scribal practices can be used to make a differentiation between psalm collections, and finally several apparent differences in the ways of composing psalms between these periods will be investigated.

\section{Functions of Psalms}

Form critics, and particularly Hermann Gunkel and Sigmund Mowinckel, have been highly influential in the discussion about the different functions of psalmody. ${ }^{20}$ They have divided the Psalms now in the MT Psalter into broad categories, like praise and lament psalms. Even though some of the smaller categories that have been suggested, like royal psalms, are debated, the larger categories are almost universally acknowledged by psalms scholars. Indeed, such a model works rather well in relation to many of the now canonical psalms, but scholars like Eileen Schuller have for a long time realized that these form-critical categories do not work in the psalmody of the late Second Temple period. ${ }^{21}$ There are several reasons why the traditional form-critical categories do not function properly when applied to this material. The most important reason is that when the functions of psalms extended beyond liturgical use during the late Persian and Hellenistic periods the form-critical categories presuming a cultic setting became useless in defining the intended setting of many of the psalms written from such new perspectives. Another important reason is that even liturgy, the cornerstone of such categories, was not monolithic, and it seems that, for instance, penitential prayer became a prominent liturgical category during the Hellenistic period. ${ }^{22}$ A similar case is psalms related to the act of exorcism, such as incantations and apotropaic prayers. ${ }^{23}$ Thus, the flaw is not so much in the categories themselves but in not adapting them to incorporate later functions of psalms as well. Moreover, the history of psalmody is to a great extent a history of interpretation and recontextualization, and hence the functions of a given psalm might have changed a number of times during its transmission, which should be taken into account when assessing its possible uses.

Thus, in order to even begin categorizing psalms in new ways, it would have to be acknowledged to a wider extent that psalms had other than liturgical functions as prayers and songs.

\footnotetext{
${ }^{20}$ Gunkel: 1962.

${ }^{21}$ E.g., Schuller: 2003, 177-179.

${ }^{22}$ See Werline: 1998. Newman: 1999. For the prominence of penitential prayer and its motifs in literature from the 2 nd and 1st centuries BCE, see, e.g., Floyd: 2007, 51-82. Chazon: 2007, 177-186. Nitzan: 2007, 187-208.

${ }^{23}$ See, for example, Eshel: 2003, 69-88.
} 
While Wilson's emphasis on the MT Psalter as a book meant for instruction has certainly been taken into account when considering the function(s) of that particular collection, this only captures a part of the functions of psalmody. Nevertheless, even in the introduction to the recent Oxford Handbook of the Psalms, William P. Brown under the heading Functions of Psalms summarizes the functions rather classically as hymnbook, prayer book and a book of (wisdom) instruction. ${ }^{24}$ However, in order to think of possible changes in the functions of psalmody it is important to realize that during the last centuries BCE and the first century CE the psalms were used both in private and in communal gatherings, and they functioned at least as prayers, sources of spiritual meditation, and as parts of different liturgies, but also as sources of historical knowledge, as prophecy and as instructions concerning social norms. In the following these aspects are studied one by one, beginning with liturgy, continuing with history and instruction, and ending with prophecy.

\subsection{Psalms as Liturgy}

Both the earlier and new psalms could have a liturgical function, and as already indicated this is the original Sitz im Leben of most of the earlier psalms. But if the Qumran group's own psalm material that is the prime evidence for the new psalms with a liturgical function (Hodayot, Songs of the Sage, possibly Songs of the Sabbath Sacrifice and the Barkhi Nafshi) is analyzed and compared with the Psalms now in the MT Psalter, there is a clear change in the overall types of psalmody. The Qumran group's own psalms are, with very minor exceptions, all grounded on praise and many, if not most, of them have a communal perspective. ${ }^{25}$ Absent are the individual and communal laments that make up almost a third of the MT Psalter. ${ }^{26}$ Some of the elements familiar from laments, such as descriptions of a situation of distress, are found in the new psalms, like the Hodayot. But they are embedded as individual elements into contexts of praise rather than forming a liturgical category of their own. Another striking detail is the sheer number of new praise oriented psalms, Songs of the Sabbath Sacrifice, Songs of the Sage, the Barkhi Nafshi hymns and many of the Hodayot are most of all liturgical pieces and they are all represented by many collections of different sizes. Together with prayer texts, such as the Daily Prayers, Festival Prayers and Words of the Luminaries, they probably formed the backbone of the communal everyday liturgical texts of the movement.

\footnotetext{
${ }^{24}$ Brown: 2014, 5.

${ }^{25}$ For praise of God as the hallmark of late Second Temple Jewish liturgies, see Pajunen: $2015 \mathrm{~b}$.

${ }^{26}$ For example, according to Mandolfo: 2014, 115, the MT Psalter has 42 laments.
} 
This shift or a new emphasis on praise in liturgies is well evident, for instance, in the Song of the Maskil included in the Community Rule, which emphasizes the role of praise and blessing in liturgy as the response to practically every occasion of everyday life (1QS 10:1-17). Even prayers that have penitential elements, like the Words of the Luminaries, culminate in praise and thanksgiving on the Sabbath day. This focus on praise is also evident in the emerging tradition where the core of the Second Temple liturgy, the praise of God and his name, is taken as one of the reasons God created humanity in the first place and it was perceived as a special obligation of the elect (cf. Ben Sira 17:910, Jubilees 2:21, Festival Prayers 1Q34 3i 6-7, 4QAdmonition on the Flood 4Q370 I 1-2), which may partly explain the Qumran movement's particular emphasis on praise. Thus, some of the earlier psalms might have been used to augment the new psalms in the everyday liturgies of the Qumran movement, but most of the earlier psalms were probably used in private piety, as was likely the case with Psalm 119, in special rituals, such as exorcism (esp. 11Q11), or during the high festivals of the year like the Passover, if they had any liturgical function at all at this point. Actually, the Psalms of praise that characterize the final two books of the current Psalter are the ones represented by most of the fragmentary manuscripts from Qumran containing some of the now canonical Psalms, not the Psalms in books one to three of the Psalter that contain the majority of the lament material. This may be partly happenstance of scroll preservation, but definitely not entirely, and furthermore, is it just another coincidence that the extant pesharim of Psalms reinterpret as prophecies almost exclusively psalms now in the beginning of the Psalter, that is, the royal psalms and the laments, not the songs of praise that most clearly continued to also have a liturgical function. And the same seems to be true for other compositions as well, such as the Eschatological Midrash. Thus, it may well be that some of the earlier psalms did not have a liturgical use at this point but were rather used primarily as prophecies whereas others continued to have a more active role in the liturgical life.

The particular emphasis placed on praising and blessing God is not a specialty of the Qumran movement during this time, and it is also worth noting that probably around this time period liturgical notices are added to some superscripts of the Septuagint Psalter (cf. Pss 24, 48, 81, 94), ${ }^{27}$ which might indicate some differences in the usage of Psalms in different groups. Based on such evidence, I would tentatively claim that the earlier psalms had very little to do with everyday liturgies of the Qumran movement. Moreover, for instance, if the Berakhot are from the annual covenant renewal ceremony, the praise of God the Creator in them may have replaced Psalms 105 and 106 or similar prayers such as the one found in Nehemiah 9 in that liturgy at some point. In the 1QS description of the ceremony there is still a reference to relating God's merciful deeds and the

\footnotetext{
${ }^{27}$ See, e.g., Schaper: 1998, 165-183.
} 
transgressions of the entire people (1QS 1:21-24) whereas the Berakhot focus solely on the yahad and contain no references to the nation's past. ${ }^{28}$ Thus, it may be that the earlier psalms were gradually used less in liturgies than before, but it is still beyond question that both earlier and new psalms had liturgical functions.

\subsection{Psalms as History and Ethical Instruction}

The perception of psalms as something other than liturgical pieces was a fundamental element in the process whereby a large Book of Psalms came to be necessary at all. The psalms first began to be studied as historical records valuable for establishing a common past, ethical instructions regarding the societal norms and values, and, finally, also as prophecy. The dimension of societal ethical instruction is rather well acknowledged, ${ }^{29}$ especially after Wilson's studies where he argued that the current shaping of the MT Psalter shows that the probable intention of the final editors was to compile a collection primarily meant for study use as instruction, as stated in Psalm 1. But the psalms were also seen as historical records testifying about particular prayers offered by David or some other prominent figure in a specific context, hence providing information about that context and the character traits of the protagonist. This aspect of psalms may have been neglected partly because the psalms are not sources of history for us, and were also seen in such a way only secondarily by the ancients as well. Thus, such a perspective does not reveal anything about the original historical context and usage of many psalms, yet the historicizing superscripts added later to many Psalms in the MT Psalter testify to the importance of this function of psalms in the Hellenistic period. ${ }^{30}$ Furthermore, many scholars have argued that the MT Psalter as a whole is intentionally divided in accordance with the history of Israel, dealing with the reign of David, the later kings, exile and the post-exilic community in turn. ${ }^{31}$ The acceptance of such a view of the MT Psalter would mean that the psalms were seen as reflecting certain historical situations by the compilers of this particular collection. Indeed, many of the earlier psalms were used in such a way in some of the literature from the second century BCE and onwards. Furthermore, psalms from this period, such as the royal psalms in 4QNon-Canonical Psalms B and Psalm 151, were often deliberately written from such a historical

\footnotetext{
${ }^{28}$ On the Berakhot, see further Pajunen, "Creation as the Liturgical Nexus of the Blessings and Curses in 4QBerakhot," in Ancient Readers and their Scriptures, forthcoming 2018).

${ }^{29}$ See, e.g., Gerstenberger: 2014, 342-346.

${ }^{30}$ For a study that takes the added historical emphasis seriously by exploring the ways in which the 13 superscripts placing psalms into specific situations in the life of David influenced the picture of David in the books of Samuel, see Johnson: 2009.

${ }^{31}$ Wilson: 1985, 199-230. Kratz: 1996, 1-34. deClaissé-Walford: 2014b, 374.
} 
perspective, and in general psalms received more and more superscriptions placing them into specific situations familiar from the broad corpus of literature dealing with the past, as is evident, for example, in the Septuagint Psalter (e.g., Pss 27, 67, 76, 80, 96, 97, 137-39, 143, 144). ${ }^{32}$ Thus, it is evident that psalms were studied intensively in the Hellenistic period, both as ethical instruction and as evidence of historical situations.

This idea that psalms could be records of historical details or vehicles of ethical instruction was then taken for granted in the first century BCE, and already slightly before this, and the contemporary authors utilized these aspects in their own writings. They did not situate their psalms in the distant past anymore, but described events from their own and their group's perspective. The Barkhi Nafshi hymns are an example of this. Whether or not they were originally written by members of the Qumran movement is debated, but they certainly would have been read as depicting scenes from the history of the movement. They mention, for instance, living formerly among gentiles and a miraculous turn of events brought about by God where past prophecies were fulfilled in the history of this group. Such a notion of the group as the elect of God who are living in the fulfillment of prophecies and some of the hints about a former exile resonate quite strongly with what is found in the Damascus document or the pesharim. Thus, the common past described in these hymns is used to form the communal identity of the later members of the movement by providing them with a link to the shared origins of the group and an authoritative interpretation of that past as a divinely constituted, long prophesied formation of an elect group. Likewise, the Psalms of Solomon discuss the recent conquest of Jerusalem by Pompey and its aftermath at length, and furthermore some scholars hold that the Hodayot contain historical clues particularly of the speaker's past (1QH 10:9$39 ; 12: 5-18 ; 13: 5-19,20-39 ; 15: 19-23$ ) and regardless of whether they actually do, they could have been perceived as holding them.

Similarly, ethical and admonitory instruction is also found in several new psalms, particularly in the Psalms of Solomon. Nor are the Hodayot offering a timeless wisdom, but one with a clearly formulated setting in a community (1QH 6:18-22 and 12:24-28), which is evident from the links between some of the Hodayot and the community organization in 1QS as well as a similar outlook on, for instance, predestination theology. Therefore, there appears to be no dividing line between the earlier and new psalms in that psalms could function as vehicles for ethical instruction and historical recollection. Yet there is a difference in that where the earlier psalms, like Psalm 1 or Psalm 119, offer ideas about general ethical behavior in accordance with societal norms and values

\footnotetext{
${ }^{32}$ E.g., Pietersma: 2001, 99-138.
} 
tied especially to the study of the Torah, the new psalms reflect the particular theological outlooks of the given community. Similarly, where the earlier psalms are typically interested in dealing with the history of the entire people, the new psalms deal with the past experiences of a particular group.

\subsection{Psalms as Prophecy}

Thus, the earliest study use of the psalms was as ethical instruction and records of the past, but eventually, probably at some point during the second century BCE, the psalms also began to be seen as prophecies. This change in the functions of psalms has been a fundamental point for many scholars, like Eugene Ulrich, when arguing for why the Book of Psalms is in the Hebrew Bible and it is certainly a noteworthy change that is an integral part of the canonical process. ${ }^{33}$ The pesharim and the New Testament offer the most explicit usage of earlier psalms in such a way. ${ }^{34}$ The earlier psalms were not written from such a perspective and typically had to be explicitly interpreted in order for their perceived prophetic message to be understood. But from the second century BCE onwards there are psalms written as prophecies, such as the third psalm in the extant portion of 4QNon-Canonical Psalms B (4Q381 IV 7-V 12), probably written in the interim period, and providing a vision of the glorious future awaiting the psalmist and his followers.

Yet the earlier and interim psalms are not unique in this respect. The Psalms of Solomon end in a prophetic vision of the future (PsSol 17 and 18), so does at least one Barkhi Nafshi hymn in 4Q434 describing the future bliss of the elect group in Jerusalem, ${ }^{35}$ and the War Scroll (1QM 11) contains a psalmic prophecy of the end-time war. Furthermore, while the original setting of Lamentations was probably well known in the Second Temple period, they are still seen as prophecies of the doom of the Second Temple by Josephus (Ant. 10.78-79), and while it is still to be investigated whether or not any of the Hodayot are presented as actual prophecies (possible cases, 1QH 7:19-20; $11: 15-18,26-36 ; 12: 18-22,14: 29-33)$, it is obvious that the writer presents himself in many of the Hodayot as a chosen mediator of divine knowledge. It is also noteworthy that this speaker does not plead for the end of his enemies as the earlier psalmists do but rather presents their judgment as an inevitable event, thus underlining his special status as a chosen mediator (cf. the prophetic utterances of Jesus in the Gospels). In light of all these psalms, it seems that the earlier psalms were not alone

\footnotetext{
${ }^{33}$ Ulrich: 2003, 3-25.

${ }^{34}$ David's Compositions (11QPs $\left.{ }^{\text {a }} 27: 11\right)$ provides an explicit statement that David composed psalms through prophecy.

${ }^{35}$ See, Pajunen: 2012, 360-363.
} 
in being regarded as prophecies, but the difference is again that unlike the new psalms, the earlier ones had to be interpreted because they were not written for such a usage.

Therefore, the functions of psalms do not form a criterion that could be used to argue for some sort of change or division. Psalms were eventually included in the canon mainly because they had been studied for hundreds of years, but this function was not limited to the currently canonical psalms. The functions of psalmody just described may help in finally deciphering in a more nuanced way the varied functions of psalms in the late Second Temple period, but they do not form a basis for differentiating between the statuses of psalms. One aspect has to be emphasized at this point. The earlier psalms frequently had to be interpreted in order to fit the contemporary functions of psalmody whereas the new pieces were already composed with these settings in mind. The reinterpretation of the earlier psalms was necessary in order for them to be meaningful to specific groups but at the same time this act of interpretation in a way set them apart from the new psalms that did not need such interpretation. I shall return to this below.

\section{Differences in Manuscript Arrangements}

There is very little in the material arrangement or scribal practices that might demonstrate a division in psalmody. This is not that surprising as, for example, Emanuel Tov has stated that there is little distinction between biblical and non-biblical at this point in time at the manuscript level. ${ }^{36}$ Nevertheless, in the following some distinct features are briefly listed, and the extent of these features in the different Qumran manuscripts containing psalms will be noted.

1) Both larger and smaller collections of psalms are evident in both earlier and new psalms so general scroll size is not a dividing marker between them. ${ }^{37}$

2) Empty spaces, vacates, are used as division markers both between psalms and stanzas in earlier as well as new psalms (cf. 4QBarkhi Nafshia and some Hodayot of the new psalms, and 4QNon-Canonical Psalms A, Psalm 91 in 11QApocrPs of the earlier ones).

3) Basically all the psalms are written in Hebrew, and nearly all are on parchment manuscripts. One Hodayot scroll is on papyrus but so is a possible psalms scroll 6Q5. ${ }^{38}$

\footnotetext{
${ }^{36}$ Tov: $2004,250-251$.

${ }^{37}$ For an overview of scroll lengths, dimensions, and writing blocks among the Dead Sea Scrolls, see Tov: $2004,74-103$.

${ }^{38}$ Tov: 2004, 47, notes that the proportion of "biblical" papyrus fragments among papyrus manuscripts is much smaller than among leather manuscripts. However, the psalms manuscripts do not attest to such a difference.
} 
4) Red ink is extremely rare in the Dead Sea Scrolls and has been suggested as a sign of liturgical use ${ }^{39}$ it is found in 2QPs containing Psalms 103 and 104, and while it is not used with the new psalms, it was used in the Damascus document (4QD $)$, showing that the use of red ink was not limited to current biblical books.

5) The existence of what Emanuel Tov calls De Luxe editions and particularly the criteria for them should be re-evaluated. ${ }^{40}$ But regardless of this, even though Tov lists several manuscripts containing earlier psalms as such editions, he also includes a manuscript of Songs of the Sabbath Sacrifice (4Q403) as a possible De Luxe manuscript, which demonstrates that both earlier and new psalms could be included in such a format.

6) Finally, one might think that orthography would be more conservative or sparing in the earlier psalms and in general this might be so, but at least a few of the manuscripts exhibiting what Tov calls Qumran scribal practice contain large collections of earlier psalms, such as $11 \mathrm{QPs}^{\mathrm{a}}$ and $b .{ }^{41}$ Of course from the point of view of a later reader, the more defectively written psalms may have at some point seemed more archaic.

Nevertheless, the only aspect related to manuscripts and scribal practices where there seems to be some kind of a marked difference between the earlier and new psalms is the use of a stichometric arrangement. It has been applied to some of the earlier psalms, especially when written alone or when a rather small number of psalms are placed in a manuscript. Psalm 119 is always written in such an arrangement and Psalm 104 nearly so. Apart from these two Psalms, some earlier psalms were at times written in stichs, as in $4 \mathrm{QPs}{ }^{\mathrm{b}}$ and $\mathrm{c}$, but mostly they are in a prose format. Tov suggests that the stichometric arrangement was used by scribes writing in the proto-Masoretic tradition. ${ }^{42}$ However, this is not convincing because there are many textually non-aligned psalms scrolls arranged in stichs, even including now apocryphal psalms at least in 4QPs ${ }^{\mathrm{f}}$, and Tov's suggestion does not explain partly stichometric cases among the manuscripts. But Tov is probably right in arguing that the arrangement relates most of all to tradition. Furthermore, Tov remarks that such an arrangement requires the strict

\footnotetext{
${ }^{39}$ See Flint: 1997, 32.

${ }^{40}$ Tov: $2004,125-130$, lists as criteria large overall manuscript size with wide top and bottom margins, calligraphy, and the frequency of scribal interventions. Especially the importance of the general scroll and margin size should be rethought. Looking at the texts Tov has listed, it is not a great surprise that the so-called De Luxe scrolls contain long compositions ("biblical" books, the War Scroll, the Temple Scroll, Jubilees, Instruction, etc.) because those would have been naturally written on large sized scrolls. A rather short composition would probably never have been written on such a scroll, yet such a composition on a smaller scroll could display beautiful layout and calligraphy with very few mistakes and not be counted as a carefully manufactured manuscript according to Tov's criteria because of its general size.

${ }^{41}$ Tov: 2004, 277-288.

42 Tov: 2012, 409-420.
} 
appliance of parallelismus membrorum, which is frequent in earlier psalms, but much more seldomly used in the new ones (cf. especially the Hodayot).

This is an interesting marker, but it tells little in itself. If the attention is lifted from the stichometric arrangement alone, it may point to a difference that may have been noticeable at some point when comparing different psalms, which is poetic style and especially the role of parallelism. But again such a rule is not absolute, some earlier and interim psalms are poetically rather dreadful (e.g., some cases in 4Q380-381) and prose-like with even ašer clauses, whereas the 4QBarkhi Nafshi hymns are poetically some of the most beautiful hymns and apply extensive parallelism. Thus, the material aspects and scribal practices yield little in the way of answers. Based on this it seems safe to say that the earlier psalms were not intentionally set apart from the new ones in this way.

\section{Differences in Compositional Style}

While the functions of psalms and their material arrangements have provided only some scattered clues to differences between the earlier and new psalms, there are several differences in compositional style that are apparent at this point in time and may have influenced at least later interpretations of these psalms in a more profound manner.

\subsection{Tetragrammaton}

The use of the divine name, the Tetragrammaton, becomes gradually rarer, but is still used in many of the interim psalms, such as Psalm 154 (cf. 4QNon-Canonical Psalms B), ${ }^{43}$ which may have been one reason this psalm was still included in the collection of psalms in 11QPs ${ }^{\mathrm{a}}$ even though it already has a specific group perspective typical of the new psalms (but in addition the psalm also uses considerable parallelism, which fits with the style of the earlier psalms). Contrary to this, the Tetragrammaton is basically not used in psalms from the $1^{\text {st }}$ century BCE onwards, and its supplanting with Adonai is blatantly obvious, for example, in the opening and closing rubrics of the Qumran Barkhi Nafshi hymns. This is naturally most of all a norm in writing, but it may have influenced the later perception of what is deemed holy and ancient.

\footnotetext{
${ }^{43}$ Psalm 154 was probably composed somewhere between 150-100 BCE, see further, Pajunen: 2013, 88.
} 


\subsection{Use of Pseudepigraphy}

The second point to be discussed is the deliberate use of pseudepigraphy. Ben Sira is typically considered some kind of watershed in this respect by writing in his own name. But genuine pseudepigraphy, the deliberate writing under the name of a famous figure, continued in some circles at least into late second century BCE psalms, such as the ones in 4QNon-Canonical Psalms B probably ascribed to David, Hezekiah, Manasseh, Josiah and Jehoiachin. In addition, later pseudepigraphic attribution of psalms to biblical figures continued after this as well, as is shown, for instance, by the Septuagint Psalter, Psalms 154-155 now assigned to Hezekiah in the Syriac versions, and the Psalms of Solomon. However, as Moshe Bernstein has noted, there is a marked difference in writing deliberately under the name of a famous ancestor and placing some traditional piece of psalmody under the name of such an ancestor. ${ }^{44}$

None of the surviving $1^{\text {st }}$ century BCE or later psalms seems to have had an original pseudepigraphic attribution to a "biblical" figure. The psalms of the Qumran movement tend to use $l^{e}$ Maskil as a title if anything at all. The Psalms of Solomon have a later title and the prayers in 1 and 2 Maccabees are placed in the mouths of the protagonists. However, rather than being a conscious decision not to use pseudepigraphic attributions any longer, this is more probably a reflection of a change in the Judean society. The new psalms written in this period are not usually meant for the entire people, but to address issues central to a specific group. Therefore, there is no need to cloak these psalms as works of persons from the past holding some authority for the larger population. On the contrary, these psalms were part of a group's own special heritage, enhancing its group identity and cohesion, and were not intended to be used outside it. At least in the psalms of the Qumran movement it is clear that they avoided making pseudepigraphic attributions to figures preceding the time of the movement nor are there explicit attributions of psalms to famous figures in the history of the movement itself, like the teacher of righteousness. ${ }^{45}$

\subsection{Group Perspective}

The third point is the group angle itself, which permeates the new psalms. Thus, where the earlier psalms typically needed to be interpreted for group use, and this is also evident in some late modifications to the MT Psalter itself, ${ }^{46}$ group psalms would have in turn needed modification to be

\footnotetext{
${ }^{44}$ Bernstein: 1999, 1-26.

${ }^{45}$ Cf. Bernstein: 1999, 25-26. Collins: 1999, 55-58.

${ }^{46}$ See Marttila: 2006.
} 
meaningful and acceptable for a larger and more heterogeneous group of people. The new psalms were not meant for a broad audience nor were they typically suitable for such a stage. They probably did not spread much outside the group itself and if they had, they might have encountered resistance because of their group specific theology and aims. The group angle was probably also the main reason why the earlier and new psalms were not placed in the same collections, ${ }^{47}$ which is again something that would have set them apart from each other from a slightly later perspective.

A clear difference that links with this perspective is that the earlier psalms and some interim psalms are quoted in other works whereas the new ones typically are not, and I wish to emphasize at this point that I mean all the earlier psalms, which also includes many psalms other than those in the MT Psalter because there is a growing amount of evidence that they were also used in later writings. But it is also true that the earlier psalms needed reinterpretation more than the works of a group itself. The earlier psalms were only seldomly composed as records of history or as prophecies whereas the group psalms were; i.e., the group psalms were written for the diverse ways psalms were used in the contemporary society whereas the earlier psalms originally had mostly liturgical aims or were intended to instruct the whole people in a different societal setting and hence had to be reinterpreted to fit into the changed functions. Thus, the earlier psalms were reinterpreted in order to be meaningful, but all this activity, brought about at least partly by a change in the historical circumstances, eventually created a division inside psalmody where none had existed before.

At this point it is also important to recall the changes noted in connection with the liturgical functions of psalms in the Qumran movement because these liturgies provide the clearest cases where earlier psalms may have been supplanted by new psalms in some cultic functions they were originally intended for. In the following quotation Jonathan Magonet describes the general nature of liturgy, which aptly captures some of the reasons why the changes in psalmody are so perceptible in this area:

Liturgies express and reinforce the identity and value systems of the particular community of worshippers. Moreover, they serve to link them with members of the community, as well as with similar communities elsewhere. Conversely, the use of particular formulations may consciously exclude others from participation. Liturgies

\footnotetext{
${ }^{47}$ Pajunen: 2013, 84-90.
} 
are adapted, altered, and manipulated in the face of changes in the circumstances of the particular community. ${ }^{48}$

Some of these statements hold true for the other functions of psalmody as well. Instead of the history of the entire people, the group's past is recalled, instead of more general societal norms and values the group's theology is taught, and instead of a future as the elect people a future of a chosen group is both prophesied by the contemporary mediators of the divine will and found embedded in prophecies made in the past.

All these different aspects serve to reinforce group identity as, for instance, Carol Newsom has indicated in her influential study dealing with how the Hodayot develop and nurture group identity. ${ }^{49}$ Many of the earlier psalms originally had similar goals or effects in identity construction but they were effective most of all in relation to creating an identity as a people with a common history, the same law, and a central place of worship. ${ }^{50}$ However, the fragmentation of the Judean society in the latter half of the second century BCE created a new discourse setting, which facilitated a need for new kinds of psalms written for the emerging specific groups. At the same time as new psalms were being written for small groups the earlier psalms were seen as more and more Davidic and tied even more firmly to past writers and events, ${ }^{51}$ thus creating a marked contrast between the earlier common heritage and the new group-specific material.

\section{Conclusions}

Hopefully, this study has at least shown that the situation in the late Second Temple period concerning the divisions of psalmody was far from clear and that there were no clear-cut boundaries. The earlier psalms were not marked off by their functions or by their material arrangements. The differences in compositional style may have been important especially at a later stage when the ancestry of specific psalms was considered. Related to this is what I consider as perhaps the most influential contribution

\footnotetext{
${ }^{48}$ Magonet: 2014, 162.

${ }^{49}$ Carol Newsom's influential study on how the Hodayot develop and nurture a group identity: Newsom: 2004, 191-345. See also the studies by Jutta Jokiranta concerning identity construction, and especially Jokiranta: 2013.

${ }^{50}$ Such aspects in relation to some psalms have been noted by van Grol: 2004, 41-70.

${ }^{51}$ An example of interpreting earlier psalms in new ways is Psalm 69. It is a Davidic psalm in both MT and LXX Psalters, but it is in 4QNon-Canonical Psalms B (4Q381) apparently interpreted as pertaining to the situation of Jehoiachin in Babylon (4Q381 IX 14-19), whereas in the New Testament gospels it is seen as a prophecy concerning Jesus (cf. Luke 23,36; John 2,17.15,25.19,28), and Paul in turn interprets the enemies of the psalmist in vv. 22-23 as the Israelites that were hardened by God (Rom 11,9-10).
} 
of the last centuries BCE for the canonization process of the psalms. This is the change in Judean society that resulted in a more composite societal makeup with different groups that had diverse agendas and where especially the literate elite was apparently more divided than before. It seems that, unlike before, the authors of new psalms chose to write primarily for their own groups and for their special needs instead of trying to influence the course of the whole people. The end result was that much of the psalmody earlier to this period, i.e., the common heritage, eventually gathered acceptance as an authoritative collection of psalms whereas the later pieces were either discarded or gained some status when reinforced with later pseudepigraphic attributions. The change in society incidentally created a number of markers where a later division in psalmody could be based. This is shown in practice by late second century BCE psalms that succeeded in gaining some authority comparable to the currently canonical psalms whereas such cases have not yet been found among the psalms from the first century BCE or later. It is fully realized that these processes are complex and that it is probably impossible to map out everything that happened during the gradual process that at some point saw the emergence of a specific authoritative Book of Psalms. But the change to a deliberate group perspective is to be considered an aspect worthy of much more study, not just regarding psalmody but other writings as well. 


\section{Bibliography}

Bernstein, M. J. 1999. "Pseudepigraphy in the Qumran Scrolls: Categories and Functions," in E. G. Chazon and M. Stone (eds.), Pseudepigraphic Perspectives: The Apocrypha and Pseudepigrapha in Light of the Dead Sea Scrolls. Proceedings of the International Symposium of the Orion Center for the Study of the Dead Sea Scrolls and Associated Literature, 12-14 January, 1997, STDJ 31 (Leiden: Brill), 1-26.

Bohak, G. 2008. Ancient Jewish Magic: A History (Cambridge: Cambridge University Press).

Brooke, G. 2011. "Canonisation Processes of the Jewish Bible in the Light of the Qumran Scrolls," in J. Dochorn (ed.), "For it is Written”: Essays on the Function of Scripture in Early Judaism and Christianity, ECCA 12 (Aarhus: Peter Lang), 13-36.

Brown, W. P. 2014. "The Psalms: An Overview," in W. P. Brown (ed.), The Oxford Handbook of the Psalms (Oxford: Oxford University Press), 1-26.

Chazon, E. 2007. "The Words of the Luminaries and Penitential Prayer in Second Temple Times," in M. Boda, D. K. Falk, and R. Werline (eds.), Seeking the Favor of God, vol. 2: The Development of Penitential Prayer in Second Temple Judaism, SBLEJL 22 (Atlanta: SBL), 177-186.

deClaissé-Walford, N. 2014a. "The Canonical Approach to Scripture and The Editing of the Hebrew Psalter," in N. deClaissé-Walford (ed.), The Shape and Shaping of the Book of Psalms: The Current State of Scholarship, SBLAIL 20 (Atlanta: SBL), 1-11.

-. 2014b. "The Meta-Narrative of the Psalter," in W. P. Brown (ed.), The Oxford Handbook of the Psalms (Oxford: Oxford University Press), 363-376.

Collins, J. J. 1999. "Pseudepigraphy and Group Formation in Second Temple Judaism," in E. G. Chazon and M. Stone (eds.), Pseudepigraphic Perspectives: The Apocrypha and Pseudepigrapha in Light of the Dead Sea Scrolls. Proceedings of the International Symposium of the Orion Center for the Study of the Dead Sea Scrolls and Associated Literature, 12-14 January, 1997, STDJ 31 (Leiden: Brill), 43-58.

Driscoll, M. J. 2010. "The Words on the Page: Thoughts on Philology, Old and New," in J. Quinn and E. Lethbridge (eds.), Creating the Medieval Saga: Version, Variability, and Editorial Interpretations of Old Norse Saga Literature (Odense: Syddansk Universitets-forlag), 87-104.

Eshel, E. 2003. "Apotropaic Prayers in the Second Temple Period," in E. G. Chazon (ed.), Liturgical Perspectives: Prayer and Poetry in Light of the Dead Sea Scrolls. Proceedings of the Fifth 
International Symposium of The Orion Center for The Study of the Dead Sea Scrolls and Associated Literature, 19- 23 January, 2000, STDJ 48 (Leiden: Brill), 69-88.

Flint, P. W. 1997. The Dead Sea Psalms Scrolls and the Book of Psalms, STDJ 27 (Leiden: Brill).

-. 2014. "The Contribution of Gerald Wilson toward Understanding the Book of Psalms in Light of the Psalms Scrolls," in N. deClaissé-Walford (ed.), The Shape and Shaping of the Book of Psalms: The Current State of Scholarship, SBLAIL 20. (Atlanta: SBL), 209-230.

Floyd, M. H. 2007. "Penitential Prayer in the Second Temple Period from the Perspective of Baruch," in M. Boda, D. K. Falk, and R. Werline (eds.), Seeking the Favor of God, vol. 2: The Development of Penitential Prayer in Second Temple Judaism, SBLEJL 22 (Atlanta: SBL), 51-82.

Gericke, J. 2014. "Philosophical Perspectives on Religious Diversity as Emergent Property in the Redaction/Composition of the Psalter," in N. deClaissé-Walford (ed.), The Shape and Shaping of the Book of Psalms: The Current State of Scholarship, SBLAIL 20 (Atlanta: SBL), 41-52.

Gerstenberger, E. S. 2014. "Non-Temple Psalms: The Cultic Setting Revisited," in W. P. Brown (ed.), The Oxford Handbook of the Psalms (Oxford: Oxford University Press), 338-349.

Grol, H. W. M. van 2004. "Psalm, Psalter, and Prayer," in R. Egger-Wenzel and J. Corley (eds.), Prayer from Tobit to Qumran: Inaugural Conference of the ISDCL at Salzburg, Austria, 5-9 July 2003, DCL Yearbook 2004 (Berlin: de Gruyter), 41-70.

Gunkel, H. 1930. Die Religion in Geschichte und Gegenwart. 2nd edition (Tübingen: J.C.B. Mohr).

—. 1933. Einleitung in die Psalmen: die Gattungen der religiösen Lyrik Israels (Göttingen: Vandenhoeck \& Ruprecht).

Jain, E. 2014. Psalmen oder Psalter? Materielle Rekonstruktion und inhaltliche Untersuchung der Psalmenhandschriften aus der Wüste Juda, STDJ 109 (Leiden: Brill).

Johnson, V. L. 2009. David in Distress: His Portrait through the Historical Psalms, JSOTSup 505 (London: T\&T Clark).

Jokiranta, J. 2013. Social Identity and Sectarianism in the Qumran Movement, STDJ 105 (Leiden: Brill).

Kratz, R. G. 1996. “Die Tora Davids. Psalm 1 und die doxologische Fünfteilung des Psalters,” ZTK 93, 1-34.

Lange, A. 2012. "Collecting Psalms in Light of the Dead Sea Scrolls," in E. Mason (ed.), A Teacher for All Generations: Essays in Honor of James C. VanderKam, JSJSup 153 (Leiden: Brill), 297-309.

Lim, T. 2013. Formation of the Jewish Canon (New Haven: Yale University Press). 
Magonet, J. 2014. “On Reading Psalms as Liturgy: Psalms 96-99," in N. deClaissé-Walford (ed.), The Shape and Shaping of the Book of Psalms: The Current State of Scholarship, SBLAIL 20 (Atlanta: SBL), 161-179.

Mandolfo, C. 2014. "Language of Lament in the Psalms," in W. P. Brown (ed.), The Oxford Handbook of the Psalms (Oxford: Oxford University Press), 114-130.

Marttila, M. 2006. Collective Reinterpretation in the Psalms: A Study of the Redaction History of the Psalter, FAT/2 13 (Tübingen: Mohr Siebeck).

Mowinckel, S. 1962. Psalms in Israel's Worship (Nashville: Abingdon).

Mroczek, E. 2011. "Thinking Digitally About the Dead Sea Scrolls: Book History Before and Beyond the Book," Book History 14, 241-269.

-. 2015. "The Hegemony of the Biblical in Second Temple Literature," JAJ 6, 2-35.

Newman, J. 1999. Praying by the Book: The Scriptualization of Prayer in Second Temple Judaism, SBLEJL 14 (Atlanta: Scholars Press).

Newsom, C. A. 2004. The Self as Symbolic Space: Constructing Identity and Community at Qumran, STDJ 52 (Leiden: Brill).

Nicholls, S. G. 2014. "New Challenges for the New Medievalism," in H. Bloch et al. (eds.), Rethinking the New Medievalism (Baltimore: Johns Hopkins University Press), 12-38.

Nitzan, B. 2007. “Traditional and Atypical Motifs in Penitential Prayers from Qumran,” in M. Boda, D. K. Falk, and R. Werline (eds.), Seeking the Favor of God, vol. 2: The Development of Penitential Prayer in Second Temple Judaism, SBLEJL 22 (Atlanta: SBL), 187-208.

Pajunen, M. S. 2012. "From Poetic Structure to Historical Setting: Exploring the Background of the Barkhi Nafshi Hymns," in C. Wassen, K. Penner, and J. Penner (eds.), Prayer and Poetry in the Dead Sea Scrolls and Related Literature: Essays in Honor of Eileen Schuller on the Occasion of Her 65th Birthday, STDJ 98 (Leiden: Brill), 355-376.

- 2013. The Land to the Elect and Justice for All: Reading Psalms in the Dead Sea Scrolls in Light of 4Q381, JAJSup 14 (Göttingen: Vandenhoeck \& Ruprecht).

-. 2014. "Perspectives on the Existence of a Particular Authoritative Book of Psalms in the Late Second Temple Period," JSOT 39, 139-163.

-. 2015a. "How to Expel a Demon? Form and Tradition Critical Assessment of the Ritual of Exorcism in 11QapocrPs," in M. S. Pajunen and H. Tervanotko (eds.), Crossing Imaginary Boundaries: The 
Dead Sea Scrolls in the Context of Second Temple Judaism, Publications of the Finnish Exegetical Society 108 (Helsinki: Finnish Exegetical Society), 128-161.

-. 2015b. "The Praise of God and His Name as the Core of the Second Temple Liturgy," ZAW 127, 475-488.

—. "Bible," in G. Brooke and C. Hempel (eds.), $T \&$ T Clark Companion to the Dead Sea Scrolls (Bloomsbury: T\&T Clark), forthcoming 2018.

-. "Creation as the Liturgical Nexus of the Blessings and Curses in 4QBerakhot," in G. V. Allen and J. A. Dunne (eds.), Ancient Readers and their Scriptures: Reading the Hebrew Bible and its Versions in Jewish and Christian Antiquity, forthcoming 2018.

Pietersma, A. 2001. "Exegesis and Liturgy in the Superscriptions of the Greek Psalter," in B. A. Taylor (ed.), X Congress of the International Organization for Septuagint and Cognate Studies, Oslo, 1998, SBLSCS 51 (Atlanta: SBL), 99-138.

Schaper, J. 1998. "Der Septuaginta-Psalter. Interpretation, Aktualiserung und liturgische Verwendung der biblischen Psalmen im hellenistischen Judentum," in E. Zenger (ed.), Der Psalter in Judentum und Christentum, HBS 18 (Freiburg: Herder), 165-183.

Schuller, E. M. 2003. "Some Reflections on the Function and Use of Poetical Texts among the Dead Sea Scrolls," in E. G. Chazon (ed.), Liturgical Perspectives: Prayer and Poetry in Light of the Dead Sea Scrolls. Proceedings of the Fifth International Symposium of The Orion Center for The Study of the Dead Sea Scrolls and Associated Literature, 19-23 January, 2000, STDJ 48 (Leiden: Brill), 173-190.

Spiegel, G. M. 2014. "Reflections on the New Philology," in H. Bloch et al. (eds.), Rethinking the New Medievalism (Baltimore: Johns Hopkins University Press), 39-50.

Tov, E. 2004. Scribal Practices and Approaches Reflected in the Texts Found in the Judean Desert, STDJ 54 (Leiden: Brill).

- 2012. "The Background of the Stichometric Arrangements of Poetry in the Judean Desert Scrolls," in J. Penner, K. M. Penner, and C. Wassen (eds.), Prayer and Poetry in the Dead Sea Scrolls and Related Literature: Essays in Honor of Eileen Schuller on the Occasion of Her $65^{\text {th }}$ Birthday, STDJ 98 (Leiden: Brill), 409-420.

Ulrich, E. 2003. "From Literature to Scripture: Reflections on the Growth of a Text's Authoritativeness," DSD $10,3-25$.

-. 2011. "The Evolutionary Production and Transmission of the Scriptural Books," in H. von Weissenberg, J. Pakkala, and M. Marttila (eds.), Changes in Scripture: Rewriting and Interpreting 
Authoritative Traditions in the Second Temple Period, BZAW 419 (Berlin: De Gruyter), 4764.

Werline, R. 1998. Penitential Prayer in Second Temple Judaism: The Development of a Religious Institution, SBLEJL 13 (Atlanta: Scholars Press).

Wilson, G. H. 1985. The Editing of the Hebrew Psalter, SBLDS 76 (Chico: Scholars Press). 